\title{
Analysis on the Relationship between GDP and Construction Based on the Data of UK and China
}

\author{
JIANG Qifa, ${ }^{1,2}$ \\ 1. Economics \& Management School \\ Wuhan University \\ Wuhan, Hubei, P. R. C.; 430072 \\ E-mail: fagenjiang3@163.com Tel: +86-136 687 49508,+86-871-6513 9947
}

\begin{abstract}
When probing into the relationship of real growth between construction and national economy, this paper finds that the value and growth rate of construction and GDP are highly related, and the situation in China is similar to UK, which is dependent on the nature of construction and its high investment multiplier. However, in China Construction and economy grow faster, and their correlation coefficient is higher than which in UK. The Catch-up Effect and Bon's Curve can explain the former question, and construction administration and industrial policy in China can explain, to some extent, the later question. It is useful to understand the law of construction development for the promotion of construction economy steadily.
\end{abstract} $U K$

Key Words-Construction; National Economy; GDP; China;

\section{INTRODUCTION}

Since the introduction of economic reforms in 1978, China has become the world's fastest-growing major economy, and now the second largest economy in the world. One way to understanding China's economy is to observe and study the evolution of an industry, for example, construction, and compare it with the similar industry in other country, for example, the United Kingdom. This comparative analysis is critical to the development of industry and the promotion of administration.

The relationship between a country's economy and the level of activity in the construction sector is one, which has been the subject of study at the macroeconomic level for a number of years[1]. Construction, as one of forerunner industries in an economy, develops quickly in accordance with Chinese economy growth. Rapid changes of Chinese social and economic environments, urbanization and industrialization, globalization, etc. have exerted great influences on the transition of Chinese construction. As Table 1 shows, nominal Added Value for construction industry increased rapidly from 13.82 billion CNY in 1978 to 2671.44 billion CNY in 2010 in China, at the same time, Chinese nominal GDP (Gross Domestic Product) increased from 364.52 billion CNY in 1978 to 40326.0 billion CNY in 2010, which indicates some relatedness between GDP and construction industry[2]. How about does this relationship show between construction and GDP? Are there any differences and similarities for this relationship and why do these differences and similarities show, if we compare the relatedness between Chinese GDP and construction industry with other countries, in particular developed countries? Now based on the data of UK and China, we will discuss the relationships between GDP and construction industry, analyze their differences and similarities, and then explain these differences and similarities.

\section{THE RELATIONSHIP BETWEEN CONSTRUCTION AND GDP IN CHINA}

From 1978 to 2010, the real annual Value Added of Construction (CVA) increases rapidly. Table I shows the nominal and real GDP, nominal and real Value Added of construction in China, and their growth rate. The average real annual growth rate for construction comes up to a high record of $10.75 \%$, in term of GDP the ratio is 1.08 , which average real annual growth rate is $9.91 \%$.

\begin{tabular}{|c|c|c|c|c|c|c|c|c|c|c|c|c|c|c|c|c|c|}
\hline Year & \begin{tabular}{|c|}
$\begin{array}{c}\text { Nominal } \\
\text { GDP }\end{array}$ \\
\end{tabular} & $\begin{array}{l}\text { Real } \\
\text { GDP }\end{array}$ & CVA & $\begin{array}{l}\text { Real } \\
\text { CVA }\end{array}$ & \begin{tabular}{|c|} 
GDP Per \\
capita
\end{tabular} & Year & $\begin{array}{c}\text { Nominal } \\
\text { GDP }\end{array}$ & $\begin{array}{l}\text { Real } \\
\text { GDP }\end{array}$ & CVA & \begin{tabular}{l|l} 
Real \\
CVA
\end{tabular} & $\begin{array}{c}\text { GDP Per } \\
\text { capita }\end{array}$ & Year & \begin{tabular}{|c|} 
Nominal \\
GDP
\end{tabular} & \begin{tabular}{l|} 
Real \\
GDP
\end{tabular} & CVA & $\begin{array}{l}\text { Real } \\
\text { CVA }\end{array}$ & $\begin{array}{c}\text { GDP Per } \\
\text { capita }\end{array}$ \\
\hline 1978 & 3645.2 & 3645.2 & 138.2 & 138.2 & \begin{tabular}{|r|}
381 \\
\end{tabular} & 1989 & \begin{tabular}{|l|}
17000.9 \\
\end{tabular} & 9889.2 & 794.0 & 408.1 & \begin{tabular}{|r|}
1519 \\
\end{tabular} & 2000 & 98000.5 & 27701.5 & 5522.3 & 1104.3 & 7858 \\
\hline 979 & 4062.6 & 3922.2 & 143.8 & 141.0 & 419 & 1990 & \begin{tabular}{|l|}
18718.3 \\
\end{tabular} & 10268.9 & 859.4 & 413.0 & 1644 & 2001 & 108068.2 & 30000.8 & 1.7 & 1179.2 & 8622 \\
\hline 1980 & 4545.6 & 4228.7 & 195.5 & 178.6 & 463 & 1991 & 21826.2 & 11211.4 & 1015.1 & 452.5 & 1893 & 2002 & 119095.7 & 32725.5 & 6465.5 & 1282.9 & 9398 \\
\hline 1981 & 4889.5 & 4450.4 & 207.1 & 184.3 & 492 & 1992 & \begin{tabular}{|l|}
26937.3 \\
\end{tabular} & 12808.0 & 1415.0 & 547.6 & 2311 & 2003 & 135174.0 & 36006.4 & 7490.8 & 1437.9 & 10542 \\
\hline 1982 & 5330.5 & 4853.5 & 220.7 & 190.6 & 528 & 1993 & \begin{tabular}{|l|}
35260.0 \\
\end{tabular} & 14596.6 & 2266.5 & 646.2 & 2998 & 2004 & 159586.8 & 39637.7 & 4.3 & 1554.8 & 12336 \\
\hline 1983 & 5985.6 & 5380.3 & 270.6 & 223.1 & 583 & 1994 & 48108.5 & 16505.9 & 2964.7 & 734.5 & 4044 & 2005 & 183618.5 & 44120.7 & 10367.3 & 1803.5 & 14185 \\
\hline 1984 & 7243.8 & 6196.8 & 316.7 & 247.3 & 695 & 1995 & 59810.5 & 18309.2 & 3728.8 & 825.6 & 5046 & 2006 & 215883.9 & 49713.7 & 12408.6 & 2114.2 & 16500 \\
\hline 1985 & 9040.7 & 7031.2 & 417.9 & 302.2 & 858 & 1996 & 70142.5 & 20141.7 & 4387.4 & 895.8 & 5846 & 2007 & 266411.0 & 56754.3 & 15296.5 & 2456.4 & 20169 \\
\hline 1986 & 10274.4 & 7653.3 & 525.7 & 350.2 & 963 & 1997 & 78060.9 & 22014.2 & 4621.6 & 919.3 & 6420 & 2008 & 315274.7 & 62222.4 & 18743.2 & 2689.8 & 23708 \\
\hline 1987 & 12050.6 & 8539.8 & 665.8 & 412.8 & 1112 & 1998 & 83024.3 & 23738.7 & 4985.8 & 1002.2 & 6796 & 2009 & 341401.5 & 67955.7 & 22398.8 & 3188.9 & 25608 \\
\hline 1988 & \begin{tabular}{|l|}
15036.8 \\
\end{tabular} & 9503.1 & 810.0 & 445.8 & 1366 & 1999 & \begin{tabular}{|l|}
88479.2 \\
\end{tabular} & 25547.5 & 5172.1 & 1045.1 & 7159 & 2010 & 403260.0 & 75049.6 & 26714.4 & 3625.6 & 29992 \\
\hline
\end{tabular}

Notes: 1. Data in this table are calculated at current prices, and the base year for constant prices is 1978 . Unit: 100 million RMB.

2. Source: the National Bureau of Statistics of China (http://www.stats.gov.cn/tjsj/ndsj/2011/indexch.htm).

Based on the data of Table I, we can set the construction real Value Added (VA, here denoted by $\boldsymbol{C} \boldsymbol{V}$ ) as 
independent variable, and the correspondent real GDP regression equation with one unknown, then we get

$$
C V=0.04495 * Y-47.66
$$

After testing we will find that the determination coefficient $\left(\rho^{2}\right)$ of the equation is 0.9898 , which indicates a high correlation between independent $(\boldsymbol{C} \boldsymbol{V})$ and dependent variables $(\boldsymbol{Y})$. If the confidence is $95 \%, F$ - test Value is 2.07E-32 and smaller than the given significance level $\alpha=$ 0.05 , which indicates that a highly significant linear relationship exists between real GDP and construction Value Added.

Positive analysis makes it clear that the construction in China. In Figure 1 we show this relationship, where we can observe that the scatter diagram reveals a significant linear relationship between real GDP and construction Value Added.

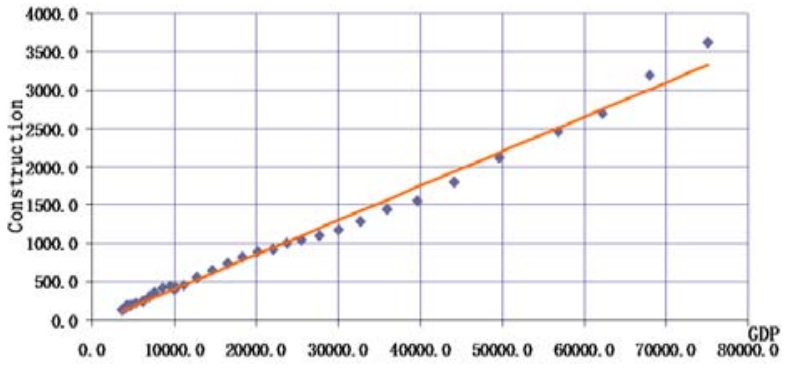

Figure 1. The Scatter Diagram between Chinese Construction VE and GDP.

Notes: 1. Data in this table are calculated at constant prices in 1978. Unit: 100 million RMB. Source: the same as Table I .

Figure 2 shows a comparison of Chinese real construction growth rate with GDP. Looking into this figure we can see that Chinese GDP and construction will hold high growth rate in the coming years. (denoted by $\boldsymbol{Y}$ ) as dependent variable, and then establish a development is highly dependent on the national economy

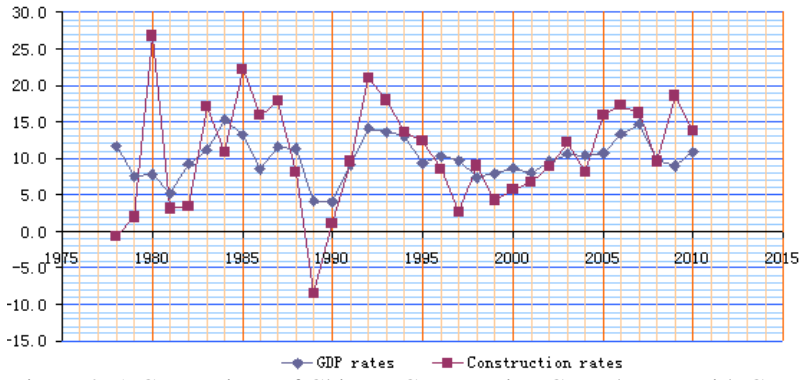

Figure 2. A Comparison of Chinese Construction Growth Rate with GDP since 1978.

Notes: 1. Data in this table are calculated at constant prices in 1978. Unit: \%. Source: the same as Table I .

2. The correlation coefficient between the GDP and construction $\rho=\mathbf{0 . 5 7 3 4}$.

\section{THE RELATIONSHIP BETWEEN CONSTRUCTION AND GDP IN UK}

Table II shows the nominal and real GDP, nominal and real Value Added of Construction (CVA) in UK, and the growth rate of GDP and construction from 1991 to 2010[3]. The average real annual growth rate for construction comes up to a high record of $3.44 \%$ (at 1995 constant prices), in term of GDP the ratio is 1.55 , which average real annual growth rate is $2.22 \%$.

Based on the data of Table II, the same as the analysis on China, we can set the construction real Value Added $(\boldsymbol{V} \boldsymbol{E}$, here denoted by $\boldsymbol{C} \boldsymbol{V})$ as independent variable, and the correspondent real GDP (denoted by $\boldsymbol{Y}$ ) as dependent variable, and then establish a regression equation with one unknown, then we get

$$
C V=0.0981 * Y-36728.08
$$

After testing we will find that the determination coefficient $\left(\rho^{2}\right)$ of the equation is 0.9519 , which indicates a high correlation between independent $(\boldsymbol{C} \boldsymbol{V})$ and dependent variables $(\boldsymbol{Y})$. If the confidence is $95 \%$, F- test Value is 2.61E-13 and smaller than the given significance level $\alpha=$ 0.05 , which indicates that a significant linear relationship exists between real GDP and construction Value Added.

\begin{tabular}{|c|c|c|c|c|c|c|c|c|c|c|c|c|c|c|c|c|c|}
\hline Year & \begin{tabular}{|c|} 
Nominal \\
GDP
\end{tabular} & $\begin{array}{l}\text { Real } \\
\text { GDP }\end{array}$ & CVA & $\begin{array}{l}\text { Real } \\
\text { CVA }\end{array}$ & \begin{tabular}{|c|} 
GDP Per \\
capita
\end{tabular} & Year & $\begin{array}{c}\text { Nominal } \\
\text { GDP }\end{array}$ & $\begin{array}{l}\text { Real } \\
\text { GDP }\end{array}$ & CVA & $\begin{array}{l}\text { Real } \\
\text { CVA }\end{array}$ & $\begin{array}{c}\text { GDP Per } \\
\text { capita }\end{array}$ & Year & $\begin{array}{c}\text { Nominal } \\
\text { GDP }\end{array}$ & $\begin{array}{l}\text { Real } \\
\text { GDP }\end{array}$ & CVA & $\begin{array}{l}\text { Real } \\
\text { CVA }\end{array}$ & $\begin{array}{c}\text { GDP Per } \\
\text { capita }\end{array}$ \\
\hline 1991 & 584536 & 649815 & 31995 & 31276 & 10111 & 1998 & 851654 & 777937 & 38945 & 36706 & 14377 & 2005 & 1253561 & 941009 & 82107 & 54759 & 20338 \\
\hline 92 & 608165 & 650288 & 29966 & 30484 & 10483 & 1999 & 891106 & 794366 & 41273 & 38790 & 14987 & 2006 & 1422479 & 982207 & 89175 & 59064 & 23479 \\
\hline 199 & 639356 & 665427 & 29144 & 30014 & 10986 & 2000 & 954004 & 834243 & 45975 & 42089 & 16187 & 2007 & 1474153 & 1017888 & 97493 & 63215 & 24172 \\
\hline 199 & 677594 & 694616 & 31347 & 31098 & 11602 & 2001 & 1005313 & 853866 & 50904 & 45590 & 16865 & 2008 & 1459885 & 1008036 & 98469 & 65672 & 23777 \\
\hline & 713980 & 713980 & 32949 & 32949 & 12181 & 2002 & 1069839 & 871450 & 55020 & 47575 & 17679 & 2009 & 1401863 & 967972 & 85575 & 65919 & 22687 \\
\hline & 756058 & 732203 & 34563 & 34052 & 12857 & 2003 & 1132938 & 894678 & 59855 & 49426 & 18643 & 2010 & 1427087 & 985389 & 83280 & 59454 & 22921 \\
\hline 997 & 805402 & 757921 & 36926 & 35268 & 13648 & 2004 & 1202075 & 923870 & 64747 & 51410 & 19663 & 2006 & 215883.9 & 49713.7 & 12408.6 & 2114.2 & 16500 \\
\hline
\end{tabular}

TABLE II. GDP AND CONSTRUCTION VALUE ADDED IN UK FROM 1991 TO 2010.

Notes: 1. Data in this table are calculated at current prices, and the base year for constant prices is 1995. Unit: Million Pounds, m£.

2. Source: The Office for National Statistics. United Kingdom National Accounts: the Blue Book 2000-2012. London: The Stationery Office, 2000-2012.

Positive analysis makes it clear that the construction development is highly dependent on the national economy in UK, too. In Figure 3 we show this relationship, where we can observe that the scatter diagram reveals a significant linear relationship between real GDP and construction
Value Added, too. 


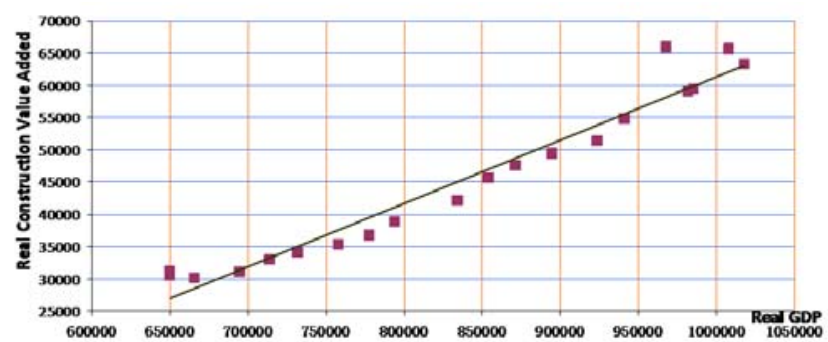

Figure 3. The Scatter Diagram between UK Construction VE and GDP. Notes: 1. Data in this table are calculated at constant prices in 1995. Unit: Million Pounds, $\mathrm{m} £$. Source: the same as Table II.

Figure 4 shows a comparison of real construction growth rate with GDP in UK. Teetering in this global recession, the trends of GDP and construction in UK are ambiguous in the following years, though in the long run they will grow.

\section{THE EXPLANATION FOR THE DIFFERENCE OF CONSTRUCTION DEVELOPMENT}

Comparing the development of construction and national economy between China and UK, we can conclude that there are differences and similarities.

Some aspects of the industry are approximately the same: construction's important role in the national economy, linear relationships between real GDP and construction Value-Added and their growth rate, though the magnitude of the correlation coefficient is different.

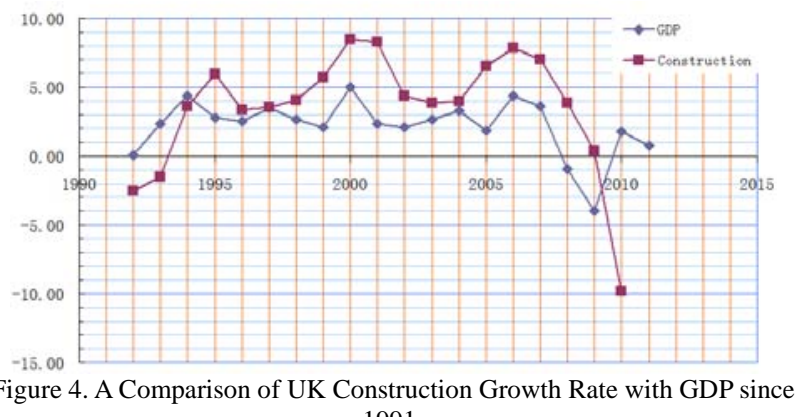
1991.

Notes: 1. Data in this table are calculated at constant prices in 1995. Unit: \%. Source: Source: the same as Table II .

2. The correlation coefficient between the GDP and construction growth rate $\rho=\mathbf{0 . 4 0 6 0}$.

The nature of construction can explain their similarities: Construction is a very important industry in any economy, intimate linkage exists between construction and many other industries.

As a forerunner industry, construction provides a high investment multiplier so it is usually used as a regulator by the governments to cope with macroeconomic problems. Thus, the growth of construction and GDP is highly related. A typical example is the 2008-2009 Chinese Economic Stimulus Plan, a RMB 4 trillion ( $£ 400$ billion) stimulus package was announced by the Central Government as an attempt to minimize the impact of the global financial crisis on 9 Nov., 2008.

However, for the relationship between construction and national economy, China is very different with UK: Firstly, construction and GDP develop very fast in China and they grow not very fast in UK.

Secondly, the relationship between construction and GDP is closer than which in UK, which is shown by the two correlation coefficients: (1) between real construction Value Added and GDP, and (2) the growth rate between real construction Value Added and GDP.

The catch-up effect and Bon's curve can explain why Chinese construction develops so fast, and the different industrial administration, in particular industrial policy, can give some explanations to the different correlation coefficients between GDP and construction.

The catch-up effect is the hypothesis that poorer economies' per capita incomes will tend to grow at faster rates than richer economies because diminishing returns (capital etc.) aren't as strong as in capital rich countries[4]. Furthermore, poorer countries can replicate production methods, technologies and institutions currently used in developed countries. Comparing with UK, because of being lower GDP per capita, construction will increase its share in GDP during Chinese take-off.

The Bon curve claim that the relationship between the share of construction in output and economic development show inverted U-shape relation[5], as Figure 5 shows. China and UK lay on each side in Bon's curve, during take-off Chinese economic growth is very high, the growth rate of construction, which is higher than GDP growth rate, will hold a significant level.

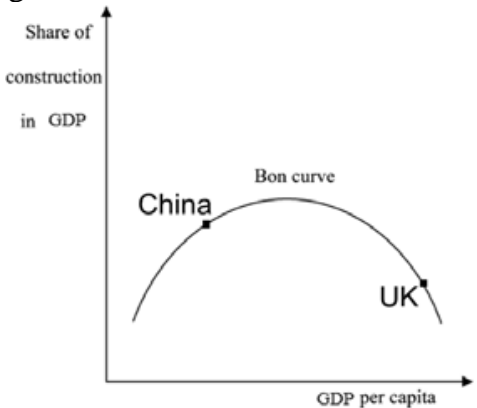

Figure 5 Bon's Curve

Being once a centralized-planning economy, governments in China have more attempts to enforce industrial policies as a regulatory tool to stimulating economic growth, as the above example, the 2008- 2009 Chinese Economic Stimulus Plan in 2008. The funds for this Plan will be invested in key areas such as housing, rural infrastructure, transportation, etc. which would undoubtedly lead an increase in construction. Industrial policies are used by governments more frequently and easily in China. As a result, the relationship between the growth of GDP and construction in China is closer than which in UK.

\section{CONCLUSIONS}

Construction shows some similarities in UK and China due to industries attributes. Construction real Value Added is highly related with GDP and a fairly high correlation coefficient exists between their growth rates. However, the 
correlation coefficients are not the same in different countries because of the development of economy, industrial administration and policies, etc. Comparing with UK, China is a later-comer, during its transition and developing stage, Chinese construction will still hold a high increasing economic growth rate in recent years. On the other hand, teetering in this global recession, the trends of GDP and construction in UK are ambiguous in the following years.

\section{REFERENCES}

[1] R. Bon. "The World Construction Market 1970-85, in Building Economics and Construction Management.” Proceedings of the CIB W65 Symposium, Sydney, 1990.

[2] The State Statistical Bureau Statistical of P.R.China. Yearbook of China 2011. Beijing: China Statistics Press, 2012, pp.30-40.

[2] The Office for National Statistics. United Kingdom National Accounts: the Blue Book 2012. London: The Stationery Office, 2012.

[4] N. Gregory Mankiw. Principles of Economics. 4th Edition. South-Western College Pub., 2006, pp.539 - 540.

[5] R. Bon. "The future of international construction: secular patterns of growth and decline”. Habitat International, Vol. 16, Autumn 1992, pp.119-28.

\section{Author Biography}

JIANG Qifa, male, doctor candidate at Wuhan University, now is a lecturer at International Business School of Yunnan University of Finance \& Economics. 